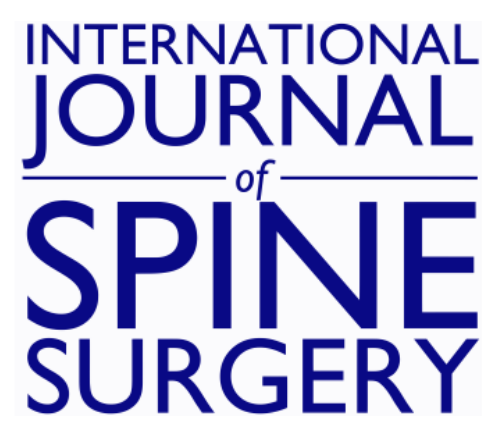

\title{
ISASS Policy Statement - Minimally Invasive Sacroiliac Joint Fusion
}

Morgan P. Lorio and Ralph Rashbaum

Int J Spine Surg 2014, 8 ()

doi: https://doi.org/10.14444/1025

http://ijssurgery.com/content/8/25

This information is current as of April 26, 2023.

Email Alerts Receive free email-alerts when new articles cite this article. Sign up at:

http://ijssurgery.com/alerts

The International Journal of Spine Surgery

2397 Waterbury Circle, Suite 1,

Aurora, IL 60504, Phone: +1-630-375-1432

(C) 2014 ISASS. All RightsoRfifereleffom http://ijssurgery.com/ by guest on April 26, 2023 


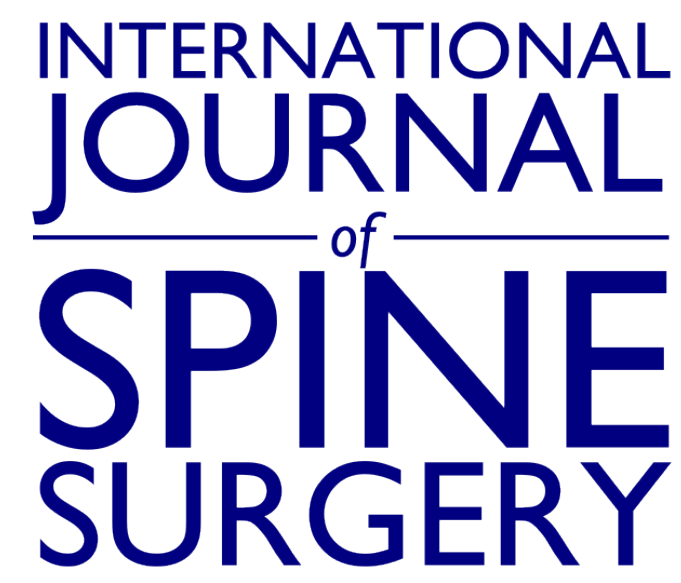

This article generously published free of charge by the International Society for the Advancement of Spine Surgery.

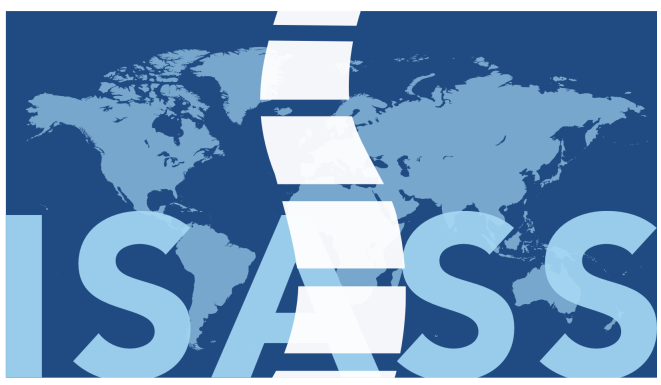

INTERNATIONAL SOCIETY for the ADVANCEMENT of SPINE SURGERY 


\title{
ISASS Policy Statement - Minimally Invasive Sacroiliac Joint Fusion
}

\author{
Morgan P. Lorio ${ }^{1}$, Ralph Rashbaum ${ }^{2}$ \\ ${ }^{1}$ Neuro-Spine Solutions, Bristol, $T N^{2}$ Texas Back Institute, Plano, TX \\ keywords: Minimally invasive surgery, sacroiliac joint fusion, policy \\ Volume 8 Article 25 doi: 10.14444/1025
}

\section{Background}

The sacroiliac (SI) joints are paired diarthrodial articulations of the sacrum and ilium and serve as the connection between the spine and pelvis. The small amount of motion in the joint (2-4 degrees) occurs primarily through nutation and counternutation of the sacrum. ${ }^{1}$ There are no muscles that cross solely the SI joint, thus there are no prime movers. Instead, movement is dependent on the articulations and movement within the lumbopelvic hip complex (e.g. flexion at the hip results in diminished lumbar lordosis and counternutation of the sacrum, extension of the lumbar spine results in nutation of the sacrum). ${ }^{2}$ The subchondral bone, capsule, and surrounding ligaments of the SI joint are rich in nociceptive pain fibers. ${ }^{3}$ Though the specific segments responsible are a subject of debate, it is generally accepted that the posterior primary rami of the lower lumbar and upper sacral segments innervate the joint. ${ }^{1}$

The SI joint is a well-known cause of pain in the lumbopelvic hip complex. ${ }^{1,4-6}$ There are many possible etiologies including, but not limited to, degenerative sacroiliitis, primary osteoarthritis, post-traumatic osteoarthritis or incongruence, adjacent joint degeneration as a result of lumbar spinal conditions and procedures, and idiopathic causes.

Low back pain (LBP) is a worldwide epidemic and one of the top 3 causes of health related chronic pain in developed countries. ${ }^{7}$ LBP is not limited to industrial countries, however, Lin et al. report devastating effects of LBP in aboriginal population of Australia ${ }^{8}$ and Hoy et al. reported that $20 \%$ of villagers in rural Tibet have substantial functional disability due to low back pain. ${ }^{9}$ Louw et al. report a $62 \%$ lifetime prevalence of LBP in Africa. ${ }^{10}$ Furthermore, low back pain is associated with increased risk of falling, ${ }^{11}$ which in an elderly population, can result in hip and/or spinal fractures. The annual expenditures for chronic back pain are astounding and exceed $\$ 100$ billion in the U.S. alone. ${ }^{12}$

While lumbar spinal structures are important factors in to consider in patients who presented with low back pain, substantial evidence suggests that the SI joint may be the pain generator in many of these patients. ${ }^{4,5,13,14}$ In patients who fail to improve after successful lumbar spinal arthrodesis, SI joint pain may explain the delayed onset of 
postoperative pain or failure to improve as a result of possible misdiagnosis or presence of other pain generators. ${ }^{15-18} \mathrm{Ha}$ et al. report radiographic evidence of SI degeneration in up to $75 \%$ of patients treated with lumbar spinal fusion. ${ }^{19}$ DePalma et al. determined the SI joint as the pain generator in $43 \%$ of patients complaining of persistent pain after lumbar spinal fusion. ${ }^{20}$

A recent study by Cher et al. reported the significance of the burden created by SI joint pain. ${ }^{21}$ The impact of SI joint pain on pain and function is commensurate with other common orthopedic conditions, such as hip and knee osteoarthritis, spinal stenosis and degenerative spondylolisthesis, all of which are treated surgically. The cost of conservative care in the patients diagnosed with SI joint disorders is substantial. Ackerman et al., using the MarketScan Commercial Claims and Encounters database, estimated an approximate cost of \$1.6billion per 100,000 covered lives (including Medicare and private insurance) for conservative treatment. Furthermore, if we assume that $15 \%$ of the $\$ 100 \mathrm{~B}$ spent on LBP should be directed at treating SI joint pain, a conservative estimate of the cost of SI joint pain is upwards of $\$ 15 \mathrm{~B}$ in the US alone. It is paramount that correctly elucidating the primary pain generator in LBP patients is crucial for adequate treatment and return to function.

\section{Diagnosing the sacroiliac joint}

SI joint pain can be difficult to diagnose as the pain syndrome may present similarly to other lumbar spinal conditions. Patients with SI joint pain typically report pain in the low back and buttocks, sometimes with radiation into the groin or upper legs. An algorithm consisting of medical history, physical examination, imaging studies and confirmatory intra-articular joint injections is typically used to diagnose SI joint disorders.

SI joint pain primary affects women over the age of $40 .{ }^{21}$ History may include mild trauma, pain during single leg stance on the affected side, difficulty sleeping, pain in the peri- or post-partum period or pain after lumbar spinal fusion. Specific physical examination tests that stress the SI joint (e.g., distraction test, compression test, thigh thrust, FABER (Patrick's) test, Gaenslen's maneuver, sacral sulcus tenderness) are performed in the physician's office. In combination, these tests are thought to be predictive of SI joint pain. ${ }^{22}$ Apart from ankylosing spondylitis, in which the diagnosis can be made based on imaging of the SI joint typically does not provide valuable diagnostic information. ${ }^{23}$ Rather, imaging is used to ensure that the patient does not have alternative diagnoses that could mimic SI joint pain (e.g., hip osteoarthritis, occasionally L5/S1 spine degeneration).

The diagnosis of SI joint pain is confirmed by performing a fluoroscopy guided intraarticular SI joint block with local anesthetic (e.g., lidocaine). Pain using a VAS scale of $0-10$ scale is assessed both prior to and within 4 hours after the block. The response time is dependent upon and is usually consistent with a short vs. long acting anesthetic and the inclusion/exclusion of epinephrine. An acute reduction in pain of at least $75 \%$ using a visual analog scale is considered a positive result and indicates that the injected joint is likely the pain generator based on published studies. ${ }^{24,25}$ SI joint blocks have been validated by a blinded study of patients who were injected with either saline or local anesthetic. ${ }^{26}$ It is important to note that one or more pathologic processes can coexist with SI joint pain. In order to confirm that SI joint pain is the primary (or only) diagnosis, the 
physician should rule out other possible causes of pelvic or lower back pain. Examples of alternative diagnoses include pelvic fracture, tumor, infection, skeletal deformity, hip arthritis, and degenerative spine conditions.

\section{Non-surgical treatment}

Non-surgical treatments available for patients suffering from SI joint pain include pain medications (e.g., non-steroid anti-inflammatory agents, opioids), physical therapy, ${ }^{27} \mathrm{a}$ pelvic compression belt, ${ }^{28}$ and manipulative therapy. If these initial treatments are unsuccessful, patients may be sent for interventional treatments such as intra-articular anesthetic and steroid injections ${ }^{29}$ and where appropriate, radio frequency (RF) ablation. ${ }^{30,31}$ Injections may provide temporary relief and in most cases will need to be repeated on a regular basis. The anesthetic phase is typically diagnostic only. A biphase approach that includes immediate relief post-anesthestic injection, followed by recurrent pain with a subsequent steroid injection may also be used. Despite positive initial results with RF ablation, recrudescence of symptoms within one year is common for many patients as a result of nerve regeneration; the SI joint is never truly denervated, it is only desensitized.

While a percentage of patients will respond well to these non-surgical measures, many of them will not experience adequate symptom relief and may be functionally disabled. Patients with a diagnosis of SI joint pain who experience pain for a minimum of six months and who do not respond to an adequate course of non-surgical treatment may be considered for SI joint fusion.

\section{Open and Minimally Invasive SI joint Fusion}

Open surgical approaches to arthrodesis of the SI joint have been available since the 1920's and can provide pain relief, but recovery times are long and the complication rate is high. ${ }^{32-36}$ Multiple incisions, damage to muscle tissue and significant intraoperative bleeding are common. Furthermore, open surgical SI joint arthrodesis requires a prolonged course of postoperative rehabilitation. Therefore, open fusion of the SI joint is commonly reserved for pelvic ring fractures in the setting of trauma. ${ }^{37}$

Minimally invasive fusion of the SI joint was first reported in the literature in 2004 and has been performed with several types of implants, including triangular, titanium plasma spray coated implants, ${ }^{38-43}$ hollow modular screws, ${ }^{44-46}$ titanium cages,${ }^{47}$ allograft ${ }^{32}$ dowels, and autograft iliac bone plugs ${ }^{48}$ (Table 1). These devices are placed either inside (posteroanterior approach) or across (lateral approach) the SI joint through relatively small incisions under fluoroscopic guidance. It is hypothesized that SI joint fusion provides acute pain relief by stabilizing the painful SI joint with subsequent fusion of the device to the sacrum and ilium, and in some cases an actual joint fusion via creeping substitution.

Table 1.

\begin{tabular}{|l|l|l|l|l|l|l|}
\hline $\begin{array}{l}\text { Author, } \\
\text { Year }\end{array}$ & $\mathrm{N}$ & Study design & Demographics & $\begin{array}{l}\text { Implant } \\
\text { description }\end{array}$ & Results & Complications \\
\hline
\end{tabular}




\begin{tabular}{|c|c|c|c|c|c|c|}
\hline $\begin{array}{l}\text { Rudolf, } \\
2012\end{array}$ & 50 & $\begin{array}{l}\text { Retrospective } \\
\text { case series }\end{array}$ & $\begin{array}{l}\text { Age: } 54 \text { years } \\
\text { Sex: } 34 \mathrm{~F} / 16 \mathrm{M} \\
\text { Prior lumbar } \\
\text { fusion: } 44 \% \\
\text { Follow up: } \\
\text { 40mo (range } \\
24-56 \text { ) }\end{array}$ & $\begin{array}{l}\text { iFuse Implant } \\
\text { System }\end{array}$ & $\begin{array}{l}\text { VAS: } 7.6 \text { pre-op, } \\
2.0 \text { at f/u } \\
\text { Mean VAS } \\
\text { improvement: }-4.3 \\
\text { pts } \\
82 \% \text { reached MCID } \\
82 \% \text { patient } \\
\text { satisfaction } \\
\text { OR time: } 65 \pm \\
\text { 26min }\end{array}$ & $\begin{array}{l}\text { Superficial cellulitis: } 3 \\
\text { Deep wound infection: } 1 \\
\text { Hematoma: } 2 \\
\text { Reoperation: } 3\end{array}$ \\
\hline $\begin{array}{l}\text { Sachs, } \\
2013\end{array}$ & 40 & $\begin{array}{l}\text { Retrospective } \\
\text { case series }\end{array}$ & $\begin{array}{l}\text { Age: } 58 \text { years } \\
\text { Sex: } 30 \mathrm{~F} / 10 \mathrm{M} \\
\begin{array}{l}\text { Prior lumbar } \\
\text { fusion: } 30 \%\end{array} \\
\begin{array}{l}\text { Follow up: } 12 \\
\text { months }\end{array}\end{array}$ & $\begin{array}{l}\text { iFuse Implant } \\
\text { System }\end{array}$ & $\begin{array}{l}\text { VAS: } 8.7 \text { pre-op, } \\
0.9 \text { at f/u } \\
\text { Mean VAS } \\
\text { improvement:- } 7.8 \text { pts } \\
98 \% \text { reached MCID } \\
100 \% \text { patient } \\
\text { satisfaction }\end{array}$ & $\begin{array}{l}\text { Piriformis syndrome: } 1 \\
\text { New LBP: } 1 \\
\text { Facet joint pain: } 8 \\
\text { Trochanteric bursitis: } 2\end{array}$ \\
\hline $\begin{array}{l}\text { Cummings, } \\
2013\end{array}$ & 18 & $\begin{array}{l}\text { Retrospective } \\
\text { case series }\end{array}$ & $\begin{array}{l}\text { Age: } 64 \text { years } \\
\text { Sex: } 12 \mathrm{~F} / 6 \mathrm{M} \\
\text { Prior lumbar } \\
\text { fusion: } 61 \% \\
\text { Follow up: } \\
12 \mathrm{mo}\end{array}$ & $\begin{array}{l}\text { iFuse Implant } \\
\text { System }\end{array}$ & $\begin{array}{l}\text { VAS: } 9.0 \text { pre-op, } \\
2.3 \text { at f/u } \\
90 \% \text { reached MCID } \\
\text { Mean improvement: } \\
\text { VAS -6.6pts, } \\
\text { ODI -37.5pts, } \\
\text { SF-12PCS } 11.2 \text {, } \\
\text { SF-12MCS } 20.4 \\
94 \% \text { very or } \\
\text { somewhat satisfied }\end{array}$ & $\begin{array}{l}\text { Trochanteric bursitis: } 3 \\
\text { Hematoma: } 1 \\
\text { Fluid retention:1 } \\
\text { Toe numbness: } 1 \\
\text { Implant malposition: } 1\end{array}$ \\
\hline $\begin{array}{l}\text { Gaetani, } \\
2013\end{array}$ & 12 & $\begin{array}{l}\text { Retrospective } \\
\text { case series }\end{array}$ & $\begin{array}{l}\text { Age: } 53 \text { years } \\
\text { Sex: } 12 \mathrm{~F} \\
\text { Prior lumbar } \\
\text { fusion: } 1 \\
\text { Follow up: } \\
10 \mathrm{mo}\end{array}$ & $\begin{array}{l}\text { iFuse Implant } \\
\text { System }\end{array}$ & $\begin{array}{l}\text { VAS: } 7.7 \text { pre-op, } \\
3.0 \mathrm{f} / \mathrm{u} \\
\text { ODI: } 31.4 \text { pre-op, } \\
12.0 \mathrm{f} / \mathrm{u} \\
100 \% \text { patient } \\
\text { satisfaction } \\
\begin{array}{l}3 \mathrm{mth} \text { CT scans } \\
\text { show initial fusion }\end{array} \\
\text { OR time: } 65 \mathrm{~min} \\
\text { EBL: }<45 \mathrm{cc}\end{array}$ & 2 local hematoma \\
\hline $\begin{array}{l}\text { Schroeder, } \\
2013\end{array}$ & 6 & $\begin{array}{l}\text { Retrospective } \\
\text { case series }\end{array}$ & $\begin{array}{l}\text { Age: } 50 \text { years } \\
\text { Sex: } 6 \mathrm{~F} / 0 \mathrm{M} \\
\text { Prior lumbar } \\
\text { fusion: } 100 \% \\
\text { (deformity } \\
\text { correction) } \\
\text { Follow up: } \\
10 \mathrm{mo}\end{array}$ & $\begin{array}{l}\text { iFuse Implant } \\
\text { System }\end{array}$ & $\begin{array}{l}\text { VAS: } 7.8 \text { pre-op, } \\
2.7 \text { at f/u } \\
\text { ODI: } 44.2 \text { pre-op, } \\
21 \mathrm{f} / \mathrm{u}\end{array}$ & None reported \\
\hline $\begin{array}{l}\text { Graham- } \\
\text { Smith, } \\
2013\end{array}$ & 114 & $\begin{array}{l}\text { Retrospective } \\
\text { multicenter, } \\
\text { comparative } \\
\text { cohort study }\end{array}$ & $\begin{array}{l}\text { Age: } 57 \text { years } \\
\text { Sex: } 82 \mathrm{~F} / 32 \mathrm{M} \\
\text { Prior lumbar } \\
\text { fusion: } 47 \% \\
\begin{array}{l}\text { Follow up: } 24 \\
\text { mo }\end{array}\end{array}$ & $\begin{array}{l}\text { iFuse Implant } \\
\text { System }\end{array}$ & $\begin{array}{l}\text { VAS: } 8.3 \text { pre-op, } \\
2.3 \text { at } 12 \mathrm{mo}, 1.7 \text { at } \\
24 \mathrm{mo} \\
86 \% \text { reached MCID } \\
\text { at } 12 \mathrm{mo}, 82 \% \text { at } \\
24 \mathrm{mo} \\
\text { OR time: } 70 \mathrm{~min} \\
\text { EBL: } 33 \mathrm{cc} \\
\text { Hospital stay: } 1.3 \\
\text { days }\end{array}$ & $\begin{array}{l}3.5 \% \text { reoperation due to nerve root } \\
\text { impingement, facet pain (4), fall (4), } \\
\text { piriformis syndrome (2), cellulitis ( } 3 \text { ), } \\
\text { trochanteric bursitis (2) }\end{array}$ \\
\hline
\end{tabular}




\begin{tabular}{|c|c|c|c|c|c|c|}
\hline $\begin{array}{l}\text { Duhon, } \\
2013\end{array}$ & $\begin{array}{l}32 \\
94\end{array}$ & $\begin{array}{l}\text { Prospective, } \\
\text { multi-center }\end{array}$ & $\begin{array}{l}\text { Age: } 50 \text { years } \\
\text { Sex: } 21 \mathrm{~F} / 11 \mathrm{M} \\
\text { Prior lumbar } \\
\text { fusion: } 69 \% \\
\text { Follow-up: } 6 \\
\text { months }\end{array}$ & $\begin{array}{l}\text { iFuse Implant } \\
\text { System }\end{array}$ & $\begin{array}{l}\text { VAS: } 76.2 \text { pre-op, } \\
29.3 \text { f/u } \\
\text { ODI: } 55.3 \text { pre-op, } \\
38.9 \text { f/u } \\
\text { SF-36PCS: } 30.7 \\
\text { pre-op, } 37 \text { f/u } \\
88.5 \% \text { success rate } \\
85 \% \text { somewhat or } \\
\text { very satisfied, } \\
\text { OR time: } 48 \mathrm{~min} \\
\text { EBL: } 59 \mathrm{cc} \\
\text { Hospital stay: } 0.8 \\
\text { days }\end{array}$ & $\begin{array}{l}\text { No implant revision or removal, } 6 \text { AEs } \\
\text { probably or definitely related to study } \\
\text { procedure ( } 1 \text { nausea, } 2 \text { wound } \\
\text { infections, } 1 \text { cellulitis, } 1 \text { buttock pain) }\end{array}$ \\
\hline $\begin{array}{l}\text { Sachs, } \\
2014\end{array}$ & 144 & $\begin{array}{l}\text { Retrospective, } \\
\text { multi-center }\end{array}$ & $\begin{array}{l}\text { Age: } 58 \text { years } \\
\text { Sex: } 30 \mathrm{~F} / 10 \mathrm{M} \\
\text { Prior lumbar } \\
\text { fusion: } 62 \% \\
\text { Follow-up: } \\
16 \mathrm{mo}\end{array}$ & $\begin{array}{l}\text { iFuse Implant } \\
\text { System }\end{array}$ & $\begin{array}{l}\text { VAS: } 8.6 \text { pre-op, } \\
2.7 \text { f/u } \\
91 \% \text { Very or } \\
\text { somewhat satisfied } \\
\begin{array}{l}91.7 \% \text { would have } \\
\text { surgery again }\end{array} \\
\text { OR time: } 73 \mathrm{~min} \\
\text { EBL: minimal } \\
\begin{array}{l}\text { Hospital stay: } 0.8 \\
\text { days }\end{array}\end{array}$ & $\begin{array}{l}\text { Implant revision (1), fall (5), } \\
\text { trochanteric bursitis (4), piriformis } \\
\text { syndrome (3), facet pain (3) }\end{array}$ \\
\hline $\begin{array}{l}\text { Al-Khayer } \\
2008\end{array}$ & 9 & $\begin{array}{l}\text { Retrospective } \\
\text { case series }\end{array}$ & $\begin{array}{l}\text { Age: } 42 \text { years } \\
\text { Sex: } 9 \mathrm{~F} \\
\text { Follow-up: } 40 \\
\text { mo }\end{array}$ & $\begin{array}{l}\text { Hollow modular } \\
\text { anchorage screw } \\
\text { packed with } \\
\text { demineralized } \\
\text { bone matrix }\end{array}$ & 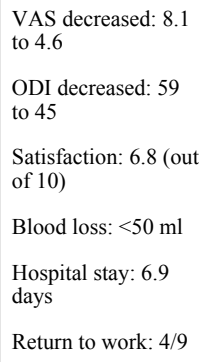 & $\begin{array}{l}1 \text { deep wound infection } \\
\text { Complication rate: } 11 \%\end{array}$ \\
\hline $\begin{array}{l}\text { Khurana, } \\
2009\end{array}$ & 15 & $\begin{array}{l}\text { Retrospective } \\
\text { case series }\end{array}$ & $\begin{array}{l}\text { Age: } 48.7 \\
\text { years } \\
\text { Sex: } 11 \mathrm{~F} / 4 \mathrm{M} \\
\text { Prior lumbar } \\
\text { fusion: } 40 \% \\
\begin{array}{l}\text { Follow-up: } 17 \\
\text { months }\end{array}\end{array}$ & $\begin{array}{l}\text { Hollow modular } \\
\text { anchorage screw } \\
\text { packed with } \\
\text { demineralized } \\
\text { bone matrix }\end{array}$ & $\begin{array}{l}\text { SF-36 PF: } 37 \text { pre- } \\
\text { op, } 80 \text { f/u } \\
\text { Majeed's: } 37 \text { pre-op, } \\
79 \text { f/u } \\
\text { Good to excellent } \\
\text { results: } 13 / 15 \\
\text { Blood loss: }<50 \mathrm{ml} \\
\begin{array}{l}\text { Hospital stay: } 2.7 \\
\text { days }\end{array}\end{array}$ & None reported \\
\hline $\begin{array}{l}\text { Mason, } \\
2013\end{array}$ & 55 & $\begin{array}{l}\text { Retrospective } \\
\text { case series }\end{array}$ & $\begin{array}{l}\text { Age: } 57 \text { years } \\
\text { Sex: } 46 \mathrm{~F} / 9 \mathrm{M} \\
\text { Prior lumbar } \\
\text { fusion: } 40 \% \\
\text { Follow up: } \\
36 \mathrm{mo}\end{array}$ & $\begin{array}{l}\text { Hollow modular } \\
\text { anchorage screw } \\
\text { packed with } \\
\text { demineralized } \\
\text { bone matrix }\end{array}$ & $\begin{array}{l}\text { VAS: } 8.1 \text { pre-op, } \\
4.5 \mathrm{f} / \mathrm{u} \\
\text { SF-36, PCS: } 26.6 \\
\text { pre-op, } 43 \mathrm{f} / \mathrm{u} \\
\text { Majeed scoring: } \\
36.9 \text { pre-op, } 64.8 \mathrm{f} / \mathrm{u}\end{array}$ & $\begin{array}{l}2 \text { cases of post-op nerve pain requiring } \\
\text { reoperation }\end{array}$ \\
\hline Wise, 2008 & 13 & $\begin{array}{l}\text { Retrospective } \\
\text { case series }\end{array}$ & $\begin{array}{l}\text { Age: } 53 \text { years } \\
\text { Sex: } 12 \mathrm{~F} / 1 \mathrm{M} \\
\text { Prior lumbar } \\
\text { fusion: } 8 / 13 \\
\text { Follow-up: } \\
29.5 \mathrm{mo}\end{array}$ & $\begin{array}{l}2 \text { Titanium cages } \\
\text { packed with BMP }\end{array}$ & $\begin{array}{l}\text { VAS improved by } \\
4.9 \text { pts } \\
\text { Leg VAS improved } \\
\text { by } 2.4 \text { pts } \\
\begin{array}{l}\text { Blood loss: }<100 \\
\text { ml }\end{array} \\
\begin{array}{l}\text { Hospital stay: } 1.7 \\
\text { days }\end{array}\end{array}$ & $\begin{array}{l}\text { Reoperation (nonunion): } 1 \\
\text { Complication and Revision rate: } 8 \%\end{array}$ \\
\hline
\end{tabular}




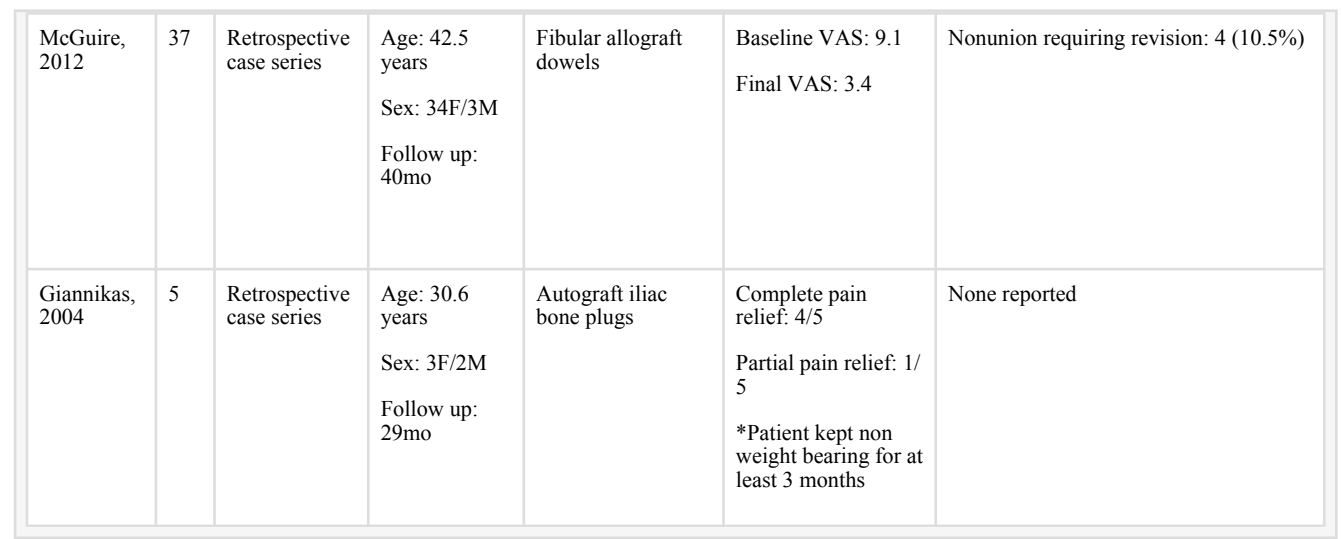

The largest body of available literature describes the use of a series of triangular titanium implants (iFuse Implant System, SI-BONE, Inc.). In addition to publication of multiple retrospective case series, ${ }^{38-41}$ published results from a prospective multicenter trial of minimally invasive SI joint fusion using triangular implants have substantiated high rates of pain relief, improvement in functional measures (SF-36, ODI and EQ-5D) and a low rate of both revisions $(<5 \%)$ and serious adverse events. ${ }^{43}$ In a multicenter retrospective comparative cohort review of 263 patients undergoing either open or minimally invasive SI joint fusion, the latter was associated with statistically significant and clinically marked decreases in operating room time (mean 163 minutes for open vs. 70 minutes for minimally invasive), decreased blood loss (mean $288 \mathrm{cc} v \mathrm{vs} .33 \mathrm{cc}$ ), and decreased hospital length of stay (5.1 vs. 1.3 days) as well as improved relief of pain (using 0-10 VAS) at 1$(-2.7$ vs. -6.2 points, $\mathrm{p}<.001)$ and 2 -year $(-2.0$ vs. -5.6 points, $\mathrm{p}<.001)$ follow-up. ${ }^{42}$

The complication rate for minimally invasive SI joint fusion is low. Importantly, the rate of removal or revision is less than $2 \% .{ }^{43-49}$ Revisions can be required in the immediate postoperative period or after many months. Early revisions may include the need to reposition an implant that is impinging on a sacral nerve or removal of an implant due to infection.

In cases of bilateral SI joint pain, bilateral SI joint fusion may occasionally be indicated and is usually performed serially to minimize the impact on rehabilitation (i.e., patients who undergo simultaneous bilateral fusion procedures may be wheelchair or bedbound for several weeks, slowing overall recovery). A frequent finding is that once the most painful side has healed (6 to 9 months), the contralateral side is often markedly improved making subsequent contralateral surgery unnecessary.

If bilateral fusion is performed at the same operative session, the surgeon must document both medical necessity and why serial fusion is not indicated in the patient. It is expected that a person would not undergo more than one SI joint fusion per side per lifetime except in the rare case that a revision is needed.

\section{Indications for surgery}

Patients who have all of the following criteria may be eligible for minimally invasive SI joint fusion: 
- Significant SI joint pain (e.g., pain rating at least 5 on the $0-10$ numeric rating scale where 0 represents no pain and 10 represents worst imaginable pain) or significant limitations in activities of daily living because of pain from the SI joint(s).

- SI joint pain confirmed with typical pain reproduction on at least 3 positive physical provocative examination maneuvers that stress the SI joint.22

- Confirmation of the SI joint as a pain generator with $\geq 75 \%$ acute decrease in pain immediately following fluoroscopically guided diagnostic intra-articular SI joint block using local anesthetic.24,25 This improvement is specifically accomplished in the immediate post-injection period whien the anesthetic agent is active (i.e., 4 hours dependent on the agent, dose level, and concentration.

- Failure to respond to at least 6 months of non-surgical treatment consisting of nonsteroidal anti- inflammatory drugs and/or opioids (if not contraindicated) and one or more of the following: rest, physical therapy, SI joint steroid injection or rhizotomy. Failure to respond means continued pain that interferes with activities of daily living and/or results in functional disability.

- Additional or alternative diagnoses that could be responsible for the patient's ongoing pain or disability have been clearly considered, investigated and ruled out.

\section{Coding and coverage history}

Minimally invasive SI joint fusion is coded using CPT code 0334T until January 1, 2015. CPT code 27280 may be recommended by payers at their individual discretion. When bilateral fusions are performed, use CPT code 0334T until January 1, 2015 on two line items with the RT (right side) and LT (left side) modifiers on each line item to indicate bilateral fusion.

Revision and/or removal of the SI joint implant is coded using 22899 (unlisted procedure, spine) or 27299 (unlisted procedure, pelvis or hip joint) depending on the type of approach and procedure performed, whether within the global period of the fusion, or not. ICD-9 codes that support medical necessity are shown in Table 2.

\begin{tabular}{|l|l|} 
Table 2. \\
\hline ICD-9 code & Description \\
\hline 720.2 & Sacroiliitis not elsewhere classified; inflammation of sacroiliac joint NOS \\
\hline 721.3 & Lumbosacral spondylosis without myelopathy \\
\hline 724.6 & Disorders of sacrum \\
\hline 739.4 & Nonallopathic lesions, not elsewhere classified in the sacral region; sacrococcygeal region or sacroiliac region \\
\hline 846.9 & Sprains and strains of the sacroiliac region, unspecified site of sacroiliac region \\
\hline 847.3 & Sprains and strains of sacrum \\
\hline
\end{tabular}




\section{Conclusion}

The prevalence of patients suffering from SI joint pain is not only high, but most likely underestimated due to improper diagnosis. Moreover, the burden of conservative care in this patient population is significant. In patients suffering from intractable SI joint pain after lumbar spinal fusion, MIS SI joint fusion is cost neutral compared to conservative care in the first year. ${ }^{50}$

Minimally invasive SI joint fusion is a safe and effective procedure for patients with unremitting pain due to SI joint disorders. Published literature consistently reports a low re-operation rate $(<5 \%)$ along with highly favorable patient outcomes; $88 \%$ average reported rate of clinically significant reduction in pain. Furthermore, these outcomes are consistent, replicable and durable across surgeons and geographic regions.

This ISASS policy does not endorse any specific MIS SIJ System. There are numerous devices available that have received FDA 510 (k) clearance for use in minimally invasive/ percutaneous sacroiliac joint fusion/stabilization. The instrumentation utilized in a MIS SIJ procedure is the purview of surgeon preference.

\section{References}

1. Vleeming A, Schuenke MD, Masi AT, Carreiro JE, Danneels L, Willard FH. The sacroiliac joint: an overview of its anatomy, function and potential clinical implications. J Anat. 2012;221(6):537-567. CrossRef

2. Indahl $\mathrm{A}$, Holm $\mathrm{S}$. The sacroiliac joint: sensory-motor control and pain. In: Movement, Stability, and Low Back Pain : The Essential Role of the Pelvis.

3. Szadek KM, Hoogland PV, Zuurmond WW, de Lange JJ, Perez RS. Nociceptive nerve fibers in the sacroiliac joint in humans. Reg Anesth Pain Med. 2008;33(1):36-43. CrossRef

4. Schwarzer AC, Aprill CN, Bogduk N. The sacroiliac joint in chronic low back pain. Spine. 1995;20(1):31-37.

5. Bernard TN, Kirkaldy-Willis WH. Recognizing specific characteristics of nonspecific low back pain. Clin Orthop. 1987;(217):266-280.

6. Fortin JD, Dwyer AP, West S, Pier J. Sacroiliac joint: pain referral maps upon applying a new injection/arthrography technique. Part I: Asymptomatic volunteers. Spine. 1994;19(13):1475-1482.

7. Salomon JA, Vos T, Hogan DR, et al. Common values in assessing health outcomes from disease and injury: disability weights measurement study for the Global Burden of Disease Study 2010. Lancet. 2012;380(9859):2129-2143. CrossRef

8. Lin IB, O’Sullivan PB, Coffin JA, Mak DB, Toussaint S, Straker LM. “I am absolutely shattered": the impact of chronic low back pain on Australian Aboriginal people. Eur J Pain Lond Engl. 2012;16(9):1331-1341. CrossRef

9. Hoy D, Toole MJ, Morgan D, Morgan C. Low back pain in rural Tibet. Lancet. 2003;361(9353):225-226. CrossRef

10. Louw QA, Morris LD, Grimmer-Somers K. The prevalence of low back pain in Africa: a systematic review. BMC Musculoskelet Disord. 2007;8:105. CrossRef 
11. Kitayuguchi J, Kamada M, Okada S, Kamioka H, Mutoh Y. Association between musculoskeletal pain and trips or falls in rural Japanese community-dwelling older adults: A cross-sectional study. Geriatr Gerontol Int. 2014. CrossRef

12. Katz JN. Lumbar disc disorders and low-back pain: socioeconomic factors and consequences. J Bone Joint Surg Am. 2006;88 Suppl 2:21-24. CrossRef

13. Sembrano JN, Polly DW. How often is low back pain not coming from the back? Spine. 2009;34(1):E27-32. CrossRef

14. Maigne JY, Aivaliklis A, Pfefer F. Results of sacroiliac joint double block and value of sacroiliac pain provocation tests in 54 patients with low back pain. Spine. 1996;21(16):1889-1892.

15. Slipman $\mathrm{CW}$, Shin $\mathrm{CH}$, Patel RK, et al. Etiologies of failed back surgery syndrome. Pain Med Malden Mass. 2002;3(3):200-214; discussion 214-217. CrossRef

16. Bolt PM, Wahl MM, Schofferman J. The Roles of the Hip, Spine, Sacroiliac Joint, and Other Structures in Patients with Persistent Pain after Back Surgery. Semin Spine Surg. 2008;20(1):14-19. CrossRef

17. Yoshihara H. Sacroiliac joint pain after lumbar/lumbosacral fusion: current knowledge. Eur Spine J Off Publ Eur Spine Soc Eur Spinal Deform Soc Eur Sect Cerv Spine Res Soc. 2012;21(9):1788-1796. CrossRef

18. Maigne JY, Planchon CA. Sacroiliac joint pain after lumbar fusion. A study with anesthetic blocks. Eur Spine J Off Publ Eur Spine Soc Eur Spinal Deform Soc Eur Sect Cerv Spine Res Soc. 2005;14(7):654-658. CrossRef

19. Ha K-Y, Lee J-S, Kim K-W. Degeneration of sacroiliac joint after instrumented lumbar or lumbosacral fusion: a prospective cohort study over five-year follow-up. Spine. 2008;33(11):1192-1198. CrossRef

20. DePalma MJ, Ketchum JM, Saullo TR. Etiology of Chronic Low Back Pain in Patients Having Undergone Lumbar Fusion. Pain Med. 2011;12(5):732-739. CrossRef

21. Cher D, Polly D, Berven S. Sacroiliac Joint pain: burden of disease. Med Devices Evid Res. 2014;7(Feburary 14):1-9.

22. Szadek KM, van der Wurff P, van Tulder MW, Zuurmond WW, Perez RSGM. Diagnostic validity of criteria for sacroiliac joint pain: a systematic review. J Pain. 2009;10(4):354-368. CrossRef

23. Tuite MJ. Sacroiliac joint imaging. Semin Musculoskelet Radiol. 2008;12(1):72-82. CrossRef

24. Dreyfuss P, Dreyer SJ, Cole A, Mayo K. Sacroiliac joint pain. J Am Acad Orthop Surg. 2004;12(4):255-265.

25. Manchikanti L, Abdi S, Atluri S, et al. An Update of Comprehensive Evidence-Based Guidelines for Interventional Techniques in Chronic Spinal Pain. Part II: Guidance and Recommendations. Pain Physician. 2013;16(2 Suppl):S49-S283.

26. Broadhurst NA, Bond MJ. Pain provocation tests for the assessment of sacroiliac joint dysfunction. J Spinal Disord. 1998;11(4):341-345.

27. Jackson R, Porter K. The Pelvis and Sacroiliac Joint: Physical Therapy Patient Management Utilizing Current Evidence. In: Current Concepts of Orthopaedic Physical Therapy.; 2006.

28. Sichting F, Rossol J, Soisson O, Klima S, Milani T, Hammer N. Pelvic belt effects on sacroiliac joint ligaments: a computational approach to understand therapeutic effects of pelvic belts. Pain Physician. 2014;17(1):43-51. 
29. Luukkainen RK, Wennerstrand PV, Kautiainen HH, Sanila MT, Asikainen EL. Efficacy of periarticular corticosteroid treatment of the sacroiliac joint in nonspondylarthropathic patients with chronic low back pain in the region of the sacroiliac joint. Clin Exp Rheumatol. 2002;20(1):52-54.

30. Cohen SP, Hurley RW, Buckenmaier CC, Kurihara C, Morlando B, Dragovich A. Randomized placebo-controlled study evaluating lateral branch radiofrequency denervation for sacroiliac joint pain. Anesthesiology. 2008;109(2):279-288. CrossRef

31. Patel N, Gross A, Brown L, Gekht G. A randomized, placebo-controlled study to assess the efficacy of lateral branch neurotomy for chronic sacroiliac joint pain. Pain Med Malden Mass. 2012;13(3):383-398. CrossRef

32. McGuire RA, Chen Z, Donahoe K. Dual fibular allograft dowel technique for sacroiliac joint arthrodesis. Evid-Based Spine-Care J. 2012;3(3):21-28.

33. Buchowski JM, Kebaish KM, Sinkov V, Cohen DB, Sieber AN, Kostuik JP. Functional and radiographic outcome of sacroiliac arthrodesis for the disorders of the sacroiliac joint. Spine J Off J North Am Spine Soc. 2005;5(5):520-528; discussion 529. CrossRef

34. Belanger TA, Dall BE. Sacroiliac arthrodesis using a posterior midline fascial splitting approach and pedicle screw instrumentation: a new technique. J Spinal Disord. 2001;14(2):118-124.

35. Waisbrod H, Krainick JU, Gerbershagen HU. Sacroiliac joint arthrodesis for chronic lower back pain. Arch Orthop Trauma Surg Arch Für Orthop Unf-Chir. 1987;106(4):238-240.

36. Moore MR. Surgical treatment of chronic painful sacroiliac joint dysfunction. In: Movement, Stability, and Low Back Pain: The Essential Role of the Pelvis. New York: Churchill Livingstone; 1997:563-572.

37. Lorio MP, Polly DW Jr, Ninkovic I, Ledonio CGT, Hallas K, Andersson G. Utilization of Minimally Invasive Surgical Approach for Sacroiliac Joint Fusion in Surgeon Population of ISASS and SMISS Membership. Open Orthop J. 2014;8:1-6. CrossRef

38. Rudolf L. Sacroiliac Joint Arthrodesis-MIS Technique with Titanium Implants: Report of the First 50 Patients and Outcomes. Open Orthop J. 2012;6:495-502. CrossRef

39. Sachs D, Capobianco R. Minimally invasive sacroiliac joint fusion: one-year outcomes in 40 patients. Adv Orthop. 2013;2013:536128. CrossRef

40. Cummings J Jr, Capobianco RA. Minimally invasive sacroiliac joint fusion: one-year outcomes in 18 patients. Ann Surg Innov Res. 2013;7(1):12. CrossRef

41. Gaetani P, Miotti D, Risso A, et al. Percutaneous arthrodesis of sacro-iliac joint: a pilot study. J Neurosurg Sci. 2013;57(4):297-301.

42. Graham Smith A, Capobianco R, Cher D, et al. Open versus minimally invasive sacroiliac joint fusion: a multi-center comparison of perioperative measures and clinical outcomes. Ann Surg Innov Res. 2013;7(1):14. CrossRef

43. Duhon B, Cher D, Wine K, Lockstadt H, Kovalsky D, Soo C-L. Safety and 6-month effectiveness of minimally invasive sacroiliac joint fusion: a prospective study. Med Devices Evid Res. 2013;6:219-229. CrossRef

44. Al-Khayer A, Hegarty J, Hahn D, Grevitt MP. Percutaneous sacroiliac joint arthrodesis: a novel technique. J Spinal Disord Tech. 2008;21(5):359-363. CrossRef 
45. Khurana A, Guha AR, Mohanty K, Ahuja S. Percutaneous fusion of the sacroiliac joint with hollow modular anchorage screws: clinical and radiological outcome. J Bone Joint Surg Br. 2009;91(5):627-631. CrossRef

46. Mason LW, Chopra I, Mohanty K. The percutaneous stabilisation of the sacroiliac joint with hollow modular anchorage screws: a prospective outcome study. Eur Spine J. 2013;22(10):2325-2331. CrossRef

47. Wise CL, Dall BE. Minimally invasive sacroiliac arthrodesis: outcomes of a new technique. J Spinal Disord Tech. 2008;21(8):579-584. CrossRef

48. Giannikas KA, Khan AM, Karski MT, Maxwell HA. Sacroiliac joint fusion for chronic pain: a simple technique avoiding the use of metalwork. Eur Spine J Off Publ Eur Spine Soc Eur Spinal Deform Soc Eur Sect Cerv Spine Res Soc. 2004;13(3):253-256. CrossRef

49. Miller L, Reckling WC, Block JE. Analysis of postmarket complaints database for the iFuse SI Joint Fusion System: a minimally invasive treatment for degenerative sacroiliitis and sacroiliac joint disruption. Med Devices Evid Res. 2013;6:77-84. CrossRef

50. Ackerman S, Knight T, Schneider K, Holt T, Cummings J, Polly D. Comparison of the costs of nonoperative care to minimally invasive surgery for sacroiliac joint disruption and degenerative sacroiliitis in a United States commercial payer population: potential economic implications of a new minimally invasive technology. Clin Outcomes Res. 2014;2014(6):283-296. CrossRef

Copyright (C) 2014 ISASS - International Society for the Advancement of Spine Surgery. To see more or order reprints or permissions, see http://ijssurgery.com. 